\title{
PENGARUH KOMPETENSI, TIM KERJA, DAN PEMBELAJARAN, TERHADAP KINERJA KARYAWAN STUDI KAUSAL DI PT. WHITESKY AVIATION
}

\author{
Dian Mustika Dewi Priyandari \\ Dosen Tetap S2 Unsurya \\ kadarwatika@yahoo.com
}

\begin{abstract}
ABSTRAK
Penelitian ini bertujuan untuk mendapatkan data fakta, dan informasi yang valid dan benar, serta dapat dipercaya tentang pengaruh Kompetensi, Tim Kerja dan Pembelajaran terhadap Kinerja Karyawan, studi kausal di PT Whitesky Aviation.

Penelitian ini dilakukan dengan menggunakan pendekatan penelitian kuantitatif, dengan menggunakan metode survei dilakukan mulai Mei s/d bulan Oktober 2017, meliputi kegiatan pra survei, konsolidasi, uji coba instrumen melalui uji validitas dan reliabilitas, serta pengumpulan dan pengolahan data hasil penelitian.

Sampel penelitian ini adalah seluruh populasi yang terjangkau, dan berkarakter sama, yaitu sebanyak 30 orang karyawan untuk uji validitas dan 100 orang karyawan untuk sampel penelitian, yang diambil secara acak sederhana, yang memenuhi syarat penelitian.

Pengukuran dalam penelitian ini dilakukan dengan memberikan nilai dari setiap butir pertanyaan dari semua variabel, ukuran nilai yang diberikan dalam setiap pernyataan menggunakan "Skala Likert".

Data yang berasal dari penyebaran kuesioner dilakukan analisis data antara lain: deskripsi data, pengujian persyaratan penelitian, meliputi: uji normalitas, uji homogenitas, dan uji linieritas. Untuk membuktikan pengaruh variabel Kompetensi $\left(\mathrm{X}_{1}\right)$ Tim Kerja $\left(\mathrm{X}_{2}\right)$, dan Pembelajaran $\left(\mathrm{X}_{3}\right)$ terhadap Kinerja $(\mathrm{Y})$ pada penelitian ini, dilakukan teknik analisis data dengan Analisis Jalur (Path Analysis).

Berdasarkan hasil analisis penelitian:

1) Terdapat pengaruh secara positif dan signifikan variabel Kompetensi $\left(\mathrm{X}_{1}\right)$ terhadap variabel Pembelajaran $\left(\mathrm{X}_{3}\right)$, secara parsial sebesar 23,01\%.

2) Terdapat pengaruh secara positif dan signifikan variabel Tim $\operatorname{Kerja}\left(\mathrm{X}_{2}\right)$ terhadap variabel Pembelajaran $\left(\mathrm{X}_{3}\right)$, secara parsial sebesar 59,59\%.

3) Terdapat pengaruh secara positif dan signifikan variabel Kompetensi $\left(\mathrm{X}_{1}\right)$ terhadap variabel Kinerja (Y), secara parsial sebesar 18,54\%.

4) Terdapat pengaruh secara positif dan signifikan variabel Tim Kerja $\left(\mathrm{X}_{2}\right)$ terhadap variabel Kinerja (Y), secara parsial sebesar 59,22\%.

5) Terdapat pengaruh secara positif dan signifikan variabel Pembelajaran $\left(X_{3}\right)$ terhadap variabel Kinerja (Y), secara parsial sebesar 16,24\%.

Kata Kunci : Kompetensi, Tim Kerja, Pembelajaran, dan Kinerja
\end{abstract}

\section{PENDAHULUAN}

\section{A. Latar Belakang Masalah}

PT. Whitesky Aviation adalah perusahaan bidang pelayanan transportasi di bidang penerbangan khususnya untuk melayani sewa pesawat terbang baik jarak dekat maupun jarak jauh dengan menggunakan pesawat maupun helikopter. 
Menyelenggarakan operasional pesawat terbang, perawatan pesawat terbang dan penyewaan pesawat terbang. Dalam peyewaan pesawat terbang bisa digunakan untuk kepentingan perorangan maupun kepentingan perusahaan. PT. Whitesky Aviation juga ikut serta membangun pendidikan di Indonesia yang dibuktikan dengan ikut andil dalam kerjasama pendidikan dan pengetahuan dengan sekolah penerbangan di Indonesia. Ikut serta memberikan solusi kemacetan ibu kota, buat para pengusaha yang terbatas waktuya dalam kegiatan bisnisnya. Dalam rangka penyelenggaraan tugas pelayanan tersebut, PT. Whitesky Aviation didukung oleh karyawan sebanyak 200 orang dari berbagai departemen.

\section{B. Identifikasi Masalah}

Berdasarkan latar belakang masalah, maka diidentifikasikan permasalahan yang berkaitan dengan kinerja karyawan di PT.Whitesky Aviation meliputi:

1) Apakah Kompetensi berpengaruh terhadap Kinerja?

2) Apakah Tim Kerja berpengaruh terhadap Kinerja?

3) Apakah Perilaku Kepemimpinan berpengaruh terhadap Kinerja?

4) Apakah Budaya Organisasi berpengaruh terhadap Kinerja Karyawan di PT. Whitesky Aviation?
5) Apakah Kepuasan Kerja berpengaruh terhadap Kinerja Karyawan di PT. Whitesky Aviation?

6) Apakah Motivasi berpengaruh terhadap Kinerja?

7) Apakah Pembelajaran berpengaruh terhadap Kinerja Karyawan di PT. Whitesky Aviation?

Dari faktor yang berpengaruh terhadap kinerja, ada beberapa faktor yang berpengaruh dominan terhadap kinerja karyawan di PT. Whitesky Aviation, maka perlu dilakukan penelitian faktor-faktor yang berpengaruh terhadap Kinerja karyawan, terkait dengan pekerjaan seharihari, yaitu faktor Kompetensi, Tim Kerja, dan Pembelajaran. Oleh karena itu, dalam penelitian ilmiah ini, yang diteliti adalah variabel Kompetensi, variabel Tim Kerja, variabel Pembelajaran dan variabel Kinerja.

\section{Pembatasan Masalah}

Masalah Sumber Daya Manusia, meliputi: Kompetensi, Tim Kerja, Pembelajaran, dan Kinerja, dikelompokkan, berdasarkan unsur-unsur perilaku organisasi yang dapat diukur secara jelas, dan diharapkan dapat menghasilkan masukan yang berarti.

Penelitian ini hanya membahas dalam lingkup karyawan di PT. Whitesky Aviation

\section{Rumusan Masalah}


Berdasarkan pembatasan masalah yang telah diuraikan diatas, maka permasalahan dalam penelitian ini dapat dirumuskan sebagai berikut:

1. Apakah Kompetensi berpengaruh terhadap Pembelajaran Karyawan di PT. Whitesky Aviation?

2. Apakah Tim Kerja berpengaruh terhadap Pembelajaran Karyawan di PT. Whitesky Aviation?

3. Apakah Kompetensi berpengaruh terhadap Kinerja Karyawan di PT. Whitesky Aviation?

4. Apakah Tim Kerja berpengaruh terhadap Kinerja Karyawan di PT. Whitesky Aviation?

5. Apakah Pembelajaran berpengaruh terhadap Kinerja Karyawan di PT. Whitesky Aviation?

\section{E. Kegunaan Hasil Penelitian}

1. Penelitian ini dapat memberikan masukan untuk pengembangan ilmu pengetahuan, khususnya pengembangan di bidang ilmu Sumber Daya Manusia (SDM) dan dapat menjadi dasar penelitian selanjutnya.

2. Penelitian ini juga dapat digunakan sebagai masukan informasi bagi PT. Whitesky Aviation dalam meningkatkan kualitas Sumber Daya Manusia dan untuk meningkatkan kinerja karyawan, yang secara langsung akan meningkatkan pencapaian kinerja karyawan di PT. Whitesky Aviation untuk pengembangan dan peningkatan kualitas organisasi di bidang penerbangan.

\section{KAJIAN TEORI, KERANGKA BERPIKIR \& PENGAJUAN HIPOTESIS}

\section{A. Kajian Teori}

Teori model integratif dari perilaku organisasi menurut Colquitt, Lepine dan Wesson (2011:9) sebagai pedoman penelitian, diilustrasikan pada gambar 2.1. sebagai berikut:

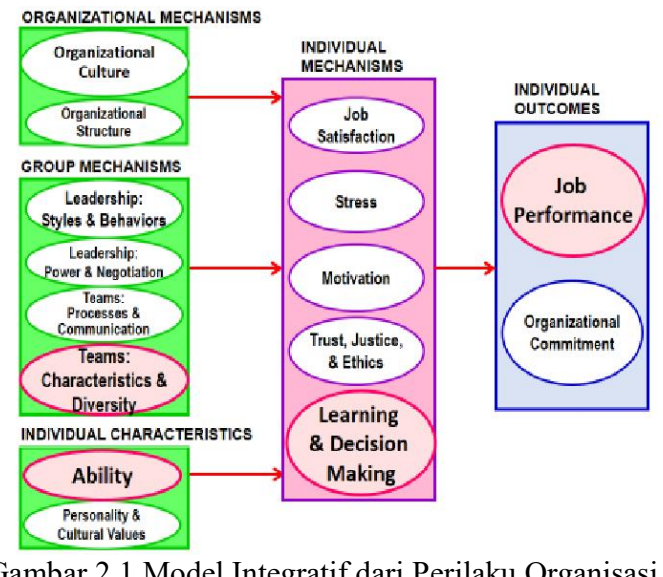

\section{Kinerja}

\section{a. Pengertian Kinerja}

Menurut Amstrong dan Baron, dikutip oleh Wibowo (2012:7), "Kinerja merupa-kan hasil pekerjaan yang mempunyai hubungan kuat dengan tujuan strategis organisasi, kepuasan konsumen, dan memberikan kontribusi ekonomi.

Colquitt, Lepine dan Wesson (2011:35), mengungkapkan bahwa: "kinerja secara formal didefinisikan sebagai nilai dari serangkaian perilaku karyawan yang memberikan kontribusi, baik secara positif maupun negatif, terhadap pencapaian tujuan organisasi”. 
Robbins dan Judge (2009:61) menyatakan bahwa: "produktivitas adalah ukuran kinerja yang mencakup efektivitas dan efisiensi, sedangkan efektivitas yaitu pencapaian tujuan-tujuan, dan efisiensi yaitu rasio hasil efektif dengan masukan yang dibutuhkan untuk mencapainya.

\section{b. Dimensi Kinerja}

Menurut Wibowo (2012:101-102):

"Terdapat tujuh indikator kinerja, meliputi: 1)tujuan, 2) motif, 3) sarana, 4) kompetensi, 5)peluang, 6) standar dan 7) umpan balik

Mondy (2008:213) menetapkan aspek kriteria kinerja karyawan yang paling umum meliputi: 1) sifat, 2)perilaku, 3)kompetensi, 4)pencapaian tujuan, dan 5) potensi perbaikan.

Dessler (2008:295) menyebutkan pertimbangan mendasar dalam mengukur kinerja karyawan meliputi dimensi sebagai berikut:1) kualitas pekerjaan, 2) kuantitas pekerjaan, 3)kesesuaian waktu pekerjaan, 4)pengembangan kompetensi dan 5)pencapaian tujuan.

Menurut Mathis dan Jackson (2006:378) bahwa: "Kinerja karyawan yang umum untuk mayoritas pekerjaan meliputi elemen sebagai berikut: 1)kuantitas dari hasil, 2) kualitas dari hasil, 3)ketepatan waktu dari hasil, 4)kehadiran, dan 5)kemampuan bekerjasama.

\section{c. Evaluasi Kinerja}

Robbins dan Judge (2009:629) menyebutkan evaluasi kinerja memiliki beberapa tujuan, meliputi: 1) menyediakan masukan untuk berbagai keputusan penting, seperti: promosi, perpindahan bagian dan pemutusan hubungan kerja, 2)mengidentifikasi kebutuhan pelatihan dan pengembangan, 3) menunjukkan kecakapan dan kompetensi dari karyawan yang saat ini kurang memadai tetapi bisa dikembangkan melalui program pelatihan, 4) menjadi kriteria yang dengan evaluasi tersebut manajemen memvalidasi seleksi dan program pengembangan, 5) digunakan oleh manajemen untuk mengidentifikasi karyawan baru yang kinerjanya buruk, 6)digunakan oleh organisasi untuk menentukan efektivitas program pengembangan dan pelatihan dengan menilai seberapa baik partisipan melakukan evaluasi kinerja mereka, 7) menyediakan umpan balik bagi karyawan tentang bagaimana organisasi melihat kinerja mereka, 8) merupakan dasar bagi alokasi imbalan.

Menurut Ivancevich, Konopaske \& Matteson (2008:168), tujuan evaluasi kinerja adalah: 1) menyediakan dasar untuk alokasi penghargaan, termasuk kenaikan gaji, promosi, transfer, pemberhentian, dan sebagainya, 2) mengidentifikasi karyawan yang berpotensi tinggi, 3) memvalidasi efektivitas dari prosedur pemilihan karyawan, 4) mengevaluasi program penilaian sebelumnya, 5) menstimulasi perbaikan kinerja, 6) mengembangkan cara untuk mengatasi hambatan dan penghambat kinerja, 
7) mengidentifikasi kesempatan pengembangan dan latihan, 8) membentuk kesepakatan supervisor-karyawan mengenai ekspektasi kinerja.

\section{d. Sintesis Kinerja}

Dari uraian di atas, maka yang dimaksud dengan kinerja adalah hasil pekerjaan seseorang dalam pelaksanaan tugas pekerjaannya dengan indikator: kualitas, ketepatan waktu, perilaku, pencapaian tujuan, dan kemampuan bekerjasama.

\section{Kompetensi}

\section{a. Pengertian Kompetensi}

Chambers (1995:2) menyebutkan sinonim ability, adalah capacity, power, talent, skill, competence, dan capability.

\section{Menurut Wibowo (2012:324),}

Kompetensi adalah suatu kemampuan untuk melaksanakan atau melakukan suatu pekerjaan atau tugas yang dilandasi atas keterampilan dan pengetahuan serta didukung oleh sikap kerja yang dituntut oleh pekerjaan tersebut. Dengan demikian kompetensi menunjukkan keterampilan atau pengetahuan yang dicirikan oleh profesionalisme dalam suatu bidang tertentu sebagai sesuatu yang terpenting, sebagai unggulan bidang tersebut.

Colquitt, LePine \& Wesson (2011:339) menyatakan bahwa: "Kompetensi menunjuk kepada kapabilitas orang yang relatif stabil untuk melaksanakan suatu jangkauan aktivitas yang berbeda tetapi terkait.

Robbins \& Judge (2009:79) mendefinisikan Kompetensi berarti kapasitas seorang individu untuk melakukan beragam tugas dalam suatu pekerjaan. "Setiap individu memiliki kekuatan dan kelemahan dalam kompetensi yang membuat relatif lebih unggul atau kurang unggul dibandingkan individu lain dalam melakukan tugas atau aktivitas tertentu.

\section{b. Dimensi Kompetensi}

Wibowo (2012:325-326), menjelaskan: "terdapa lima karakteristik kompetensi, meliputi: 1) motif, 2) sifat, 3) konsep diri, 4)pengetahuan, dan 5)keterampilan.

Colquitt, LePine dan Wesson (2011:356) menjelaskan Kompetensi karyawan secara menyeluruh, meliputi 1)Kompetensi Kognitif (verbal, kuantitatif, memberi alasan, mengenai ruang dan kecerdasan), 2)Kompetensi Emosional (kesadaran terhadap diri sendiri, kesadaran terhadap yang lain, pengaturan Emosi dan penggunaan Emosi) dan 3)Kompetensi Fisik (kekuatan, stamina, koordinasi dan fleksibel, psychomotor dan sensor).

Kreitner dan Kinicki

(2008:139) mengungkapkan, kompetensi yang diperlukan untuk melakukan berbagai pekerjaan, yang digunakan sebagai dasar untuk keputusan tentang mempekerjakan, pelatihan, promosi, dan masalah sumber daya manusia lainnya, kompetensi yang 
diinginkan, meliputi: 1) pengetahuan, 2)sikap, 3)ketrampilan, 4) komunikasi lisan, 5)inisiatif, 6) ketegasan, 7) toleransi, 8)pemecahan masalah, 9) kemampuan beradaptasi, dan 10)ketahanan.

Ivancevich, Konopaske dan Matteson (2008:66) menyatakan bahwa: "Inteligensi emosi merujuk pada kompetensi seseorang untuk 1) menyadari perasaan, 2) mengelola emosi, 3) memotivasi diri sendiri, 4) mengekspresikan empati, dan 5) menangani hubungan dengan orang lain

\section{c. Type Kompetensi}

Wibowo (2012:328-330), menjelaskan: "ada beberapa tipe kompetensi":

1) Planning competency, dikaitkan dengan tindakan tertentu seperti menetapkan tujuan, menilai risiko dan mengembangkan urutan tindakan untuk mencapai tujuan.

2) Influence competency, dikaitkan dengan tindakan tertentu seperti mempunyai dampak pada orang lain, memaksa melakukan tindakan tertentu atau membuat keputusan tertentu, dan memberi inspirasi untuk bekerja menuju tujuan organisasional.

3) Communication competency, dalam bentuk kemampuan berbicara, mendengarkan orang lain, komunikasi tertulis dan nonverbal.

4) Interpersonal competency, meliputi empati, membangun konsensus, networking, persuasi, negosiasi, diplomasi, manajemen konflik, menghargai orang \&menjadi team player.

5) Thinking competency, berkenaan dengan berpikir strategis, berpikir analitis, berkomitmen terhadap tindakan, memerlukan kemampuan kognitif, mengidentifikasi mata rantai, dan membangkitkan gagasan kreatif.

6) Organizational competency, meliputi kemampuan merencanakan pekerjaan, mengorganisasi sumber daya, mendapatkan pekerjaan dilakukan, mengukur kemajuan, dan mengambil risiko yang diperhitungkan.

7) Human resources management competency, merupakan kemampuan dalam bidang team building, mendorong partisipasi, mengembangkan bakat, mengusahakan umpan balik kinerja, dan menghargai keberagaman.

8) Leadership competency, merupakan kompetensi meliputi kecakapan memposisikan diri, pengembangan organisasional, mengelola transisi, orientasi strategis, membangun visi, merencanakan masa depan, menguasai perubahan dan mempelopori kesehatan tempat kerja.

9) Client service competency, kompetensi berupa: mengidentifikasi dan menganalisis pelanggan, orientasi pelayanan dan pengiriman, bekerja dengan pelanggan, tindak lanjut dengan 
pelanggan, membangun partnership dan berkomitmen terhadap kualitas.

10) Business competency, merupakan kompetensi yang meliputi: manajemen finansial, keterampilan pengambilan keputusan bisnis, bekerja dalam sistem, menggunakan ketajaman bisnis, membuat keputusan bisnis dan membangkitkan pendapatan.

11) Self management competency, kompetensi berkaitan dengan menjadi motivasi diri, bertindak dengan percaya diri, mengelola pembelajaran diri, mendemonstrasikan fleksibilitas dan berinisiatif.

12) Technical / operational competency, kompetensi berkaitan dengan mengerjakan tugas kantor, bekerja dengan teknologi komputer, menggunakan peralatan lain, mendemonstrasikan keahlian teknis dan professional, dan membiasakan bekerja dengan data dan angka.

\section{d. Pengaruh Kompetensi terhadap Pembelajaran}

Kreitner dan Kinicki (2008:245) mengungkapkan pengaruh Kompetensi terhadap Pembelajaran.

Noe et al. (2008:276) mengungkapkan Kompetensi salah satu faktor yang mempengaruhi kinerja karyawan dan pembelajaran.

\section{e. Pengaruh Kompetensi terhadap Kinerja}

Colquitt, LePine dan Wesson (2011:357)menyatakan bahwa: "Kompetensi Kognitif, memiliki pengaruh yang kuat secara positif terhadap Kinerja Tugas.

Robbins dan Judge

(2009:99) menyebutkan bahwa: "Kompetensi secara langsung mempengaruhi tingkat kinerja dan kepuasan karyawan melalui kesesuaian kompetensi dan pekerjaan.

Kreitner dan Kinicki (2008:138) mengungkapkan bahwa: "Kinerja yang berhasil tergantung pada kombinasi yang tepat dari usaha, kompetensi, dan ketrampilan

\section{f. Sintesis Kompetensi}

Dari uraian di atas, maka yang dimaksud dengan Kompetensi adalah kapasitas seseorang untuk melakukan beragam tugas pekerjaan, untuk menunjukkan prestasi pada berbagai tugas dalam suatu pekerjaan, dengan indikator: pengetahuan, keterampilan, inisiatif, pemecahan masalah, dan kemampuan beradaptasi.

\section{Tim Kerja}

\section{a. Pengertian Tim Kerja}

Colquitt, Lepine dan Wesson (2011: 375) mengungkapkan bahwa, Tim kerja adalah Sebuah tim terdiri dari dua orang atau lebih yang bekerja dan saling 
bergantung satu sama lain selama beberapa periode waktu untuk mencapai tujuan bersama yang terkait dengan beberapa tujuan yang berorientasi pada tugas.

Menurut Robbins dan Judge (2009:357), Tim kerja adalah kelompok yang usahausaha individualnya menghasilkan kinerja lebih tinggi daripada jumlah masukan individual. Tim kerja menghasilkan sinergi positif melalui usaha yang terkoordinasi. Tim kerja dan kelompok kerja adalah dua hal yang berbeda. Kelompok kerja adalah kelompok yang berinteraksi terutama untuk berbagi informasi dan membuat berbagai keputusan untuk membantu setiap anggota bekerja di dalam area tanggung jawabnya.

\section{b. Dimensi Tim Kerja}

Newstrom (2011:339) mengungkapkan bahwa: "Banyak penelitian telah dilakukan dalam upaya untuk mengisolasi faktor yang berkontribusi paling langsung terhadap keberhasilan tim. Dimensi umum yang diidentifikasi meliputi: 1) komposisi-hati, 2)berbagi informasi, 3)arah yang jelas, 4)target yang terukur, 5)akuntabilitas, 6)sumber daya yang cukup, 7) integrasi, 8)koordinasi, 9) fleksibilitas, 10)inovasi, dan 11) stimulasi keterbukaan untuk belajar.

Robbin dan Judge (2009:364) mengungkapkan bahwa, Tim kerja memiliki hal-hal yang membentuk perilaku anggota, untuk menjelaskan dan meramalkan sebagian besar perilaku individu dalam tim kerja dan kinerja tim itu sendiri. Hal tersebut meliputi: 1) peran, 2)norma, 3)status, 4) ukuran tim, dan 5) kohesivitas.

Luthans (2008:307) menyatakan bahwa: Difinisi komprehensif menyatakan bahwa jika ada sebuah tim di dalam organisasi, maka anggotanya: 1)Termotivasi untuk bergabung, 2) Merasa bahwa tim adalah tempat untuk saling berinteraksi dan sebuah kesatuan unit. 3) Memiliki berbagai kontribusi dalam proses organisasi (yaitu, beberapa orang memiliki kontribusi dalam hal waktu, atau energi lebih dari yang lainnya), 4) Memiliki berbagai pendapat yang disetujui maupun tidak disetujui melalui berbagai bentuk interaksi.

Ivancevich, Konopaske dan Matteson, (2008:266) menyatakan dimensi Tim kerja, merupakan karakter kelompok, meliputi: 1)komposisi, 2)hierarki status, 3) peran, 4)norma, 5) kepemimpinan dan 6)kohesivitas.

\section{c. Karakteristik Tim Kerja yang}

Efektif.

Menurut Robbins dan Judge (2009: 160161), Komponen utama yang membentuk tim yang efektif dapat digolongkan menjadi empat kategori umum: 1) Berbagai sumber dan pengaruh kontektual lain yang menjadikan tim efektif; 2) Berhubungan dengan komposisi tim; 3) Rancangan pekerjaan; 4) Variabel proses mencerminkan 
hal-hal yang terjadi di dalam tim yang mempengaruhi efektivitas.

Kreitner dan Kinicki (2008: 313) mengungkapkan:“ Karakteristik Tim kerja yang efektif meliputi: 1) Tujuan Jelas, 2) Tidak Formal, 3) Partisipasi, 4)Mendengarkan, 5) Ketidak-setujuan yang beradab, 6) Keputusan kesepakatan, 7)Komunikasi terbuka,

8) Peran dan Penugasan kerja jelas, 9) Berbagi kepemimpinan, 10) Hubungan luar, 11) Keberagaman gaya, 12) Penilaian diri.

\section{d. Pengaruh Tim Kerja terhadap \\ Pembelajaran.}

Kreitner dan Kinicki (2008:245) mengungkapkan pengaruh Tim Kerja terhadap Pembelajaran.

Colquitt, LePine \& Wesson, (2011:373) mengungkapkan pengaruh Tim Kerja terhadap Pembelajaran.

\section{e. Pengaruh Tim Kerja terhadap Kinerja}

Menurut Robbins dan Coulter (2014:300), Tim Kerja berpengaruh terhadap Kinerja, pada Model Kepuasan Kinerja Tim.

Robbins dan Judge (2009:431) menyebutkan, Tim Kerja berpengaruh langsung terhadap Kinerja, disajikan pada Teori Path-Goal.

Kreitner dan Kinicki (2008:477) mengungkapkan bahwa Tim kerja berpengaruh terhadap Kinerja Tim Kerja, terlihat pada teori jalur tujuan Hause.

\section{e. Sintesis Tim Kerja}

Dari uraian di atas, maka yang dimaksud dengan Tim Kerja adalah Tim yang harus memiliki tujuan bersama, memiliki perpaduan dari keterampilan dan kemampuan yang diperlukan dan bersamasama mempertanggung jawabkan hasil pekerjaan, dengan indikator: norma, koordinasi, komposisi, integrasi, dan kontribusi.

\section{Pembelajaran}

\section{a. Pengertian Pembelajaran}

Robbins dan Judge (2009:51), menyatakan bahwa: "definisi pembelajaran yang secara umum dapat diterima adalah setiap perubahan perilaku yang relatif permanen, terjadi sebagai hasil dari pengalaman". Dan disimpulkan bahwa: "pembelajaran telah terjadi ketika seorang individu berperilaku, bereaksi dan merespons sebagai hasil dari pengalaman dengan satu cara yang berbeda dari caranya berperilaku sebelumnya".

Noe,et.al. (2008:267), mengemukakan bahwa : "Pembelajaran secara terus menerus adalah sistem pembelajaran yang mensyaratkan para karyawan untuk memahami seluruh proses pekerjaan dan mengharapkannya untuk memperoleh keterampilan-keterampilan yang baru dan menerapkannya ke dalam pekerjaan, dan berbagi hal-hal yang telah mereka pelajari dengan karyawan lainnya".

Mathis \& Jackson (2006:306-312), menyatakan bahwa: "Bekerja dalam 
organisasi haruslah menjadi proses pembelajaran yang berkelanjutan, dan pembelajaran adalah fokus dari semua aktivitas pelatihan".

\section{b. Dimensi Pembelajaran}

Colquitt, LePine dan Wesson, (2011:260) menyampaikan: "dimensi pembelajaran adalah 1) Kreativitas, 2) Ide baru, 3) Menciptakan pengetahuan baru, 4)Informasi baru, 5) Transfer pengetahuan, 6)Perubahan perilaku 7) Penyebaran Pengetahuan baru dan 8)Komunikasi”.

Menurut Kreitner dan Kinicki (2008:502), dimensi Pembelajaran meliputi: 1)Kreativitas, 2) Ide baru, 3) Menciptakan pengetahuan baru, 4)Informasi baru, 5)Transfer pengetahuan, 6) Perubahan perilaku 7) Penyebaran Pengetahuan baru dan 8) Wawasan baru.

Mathis \& Jackson (2006:306-312), menyatakan bahwa: "Bekerja dalam organisasi haruslah menjadi proses pembelajaran yang berkelanjutan, dan pembelajaran adalah fokus dari semua aktivitas pelatihan. Pelatihan adalah strategis jika; 1)mengembangkan kapabilitas mendasar dari para pekerja, 2)mendorong kemampuan beradaptasi pada perubahan, 3)memajukan pembelajaran berkelanjutan dalam organisasi, 4)menciptakan pengetahuan baru, 5)menyebarkan pengetahuan baru di seluruh organisasi, dan 6) memfasilitasi komunikasi dan 7) fokus.

\section{c. Sistem Manajemen Pembelajaran}

Noe,et.al. (2008: 303), mengemukakan, Sistem manajemen pembelajaran mengacu pada pentas teknologi yang dapat digunakan untuk mengotomatisasi administrasi, pengembangan, dan penyampaian seluruh program pelatihan perusahaan, yang dapat memberikan kemampuan untuk mengelola, mengirim dan melacak aktivitas-aktivitas pembelajaran kepada para karyawan, pimpinan dan pelatih.

Menurut Mondy (2008:164), sistem manajemen pembelajaran bergerak melampaui penyampaian proyek-proyek pelatihan taktis ke arah pemrakarsaan program-program pembelajaran yang terkait dengan tujuan-tujuan stratejik perusahaan. Program-program pelatihan kini diakui dapat memperkuat kepuasan pelanggan, berkontribusi pada pengembangan kemitraan, mendorong aktivitas-aktivitas riset dan pengembangan, dan akhirnya meningkatkan hasil akhir. Reputasi sebagai perusahaan yang mendorong karyawannya untuk terus tumbuh dan belajar bisa menjadi nilai tambah utama dalam rekrutmen.

\section{d. Pengaruh Pembelajaran terhadap Kinerja \\ Menurut Colquitt, LePine dan Wesson} (2011:279), pembelajaran memiliki pengaruh positif terhadap kinerja. Karyawan yang memperoleh lebih banyak pengetahuan dan keahlian cenderung untuk memiliki tingkat kinerja tugas yang lebih tinggi.

Menurut Mondy

(2008:164), Peningkatan kinerja adalah tujuan akhir 
pelatihan dan pengembangan yang merupakan tujuan stratejik bagi organisasi, yang berusaha menjadi organisasi pembelajar. Organisasi pembelajar adalah suatu perusahaan yang menyadari pentingnya pelatihan dan pengembangan yang terkait dengan kinerja berkelanjutan dan mau mengambil tidakan yang tepat. Hal ini berarti pembelajaran berpengaruh terhadap kinerja.

Mathis dan Jackson (2006:114), mengungkapkan bahwa: "Tiga faktor utama yang mempengaruhi kinerja individu, adalah: 1)kemampuan individual untuk melakukan pekerjaan tersebut, 2)tingkat usaha yang dicurahkan, dan 3) dukungan organisasi (diantaranya Pelatihan dan Pengembangan yang merupakan proses pembelajaran).

\section{e. Sintesis Pembelajaran}

Dari uraian di atas, yang dimaksud dengan Pembelajaran adalah setiap perubahan perilaku yang relatif permanen, sebagai hasil dari pengalaman secara terus menerus dalam memperoleh pengetahuan dan berbagai keterampilan untuk memahami dan menerapkannya pada seluruh proses pekerjaan, dengan indikator: kreativitas, pengembangan kapabilitas, dorongan perubahan, pembelajaran berkelanjutan, dan penciptaan pengetahuan baru.

\section{B. Kerangka Berpikir}

Penelitian ini bertujuan untuk mengukur pengaruh kompetensi, tim kerja, dan pembelajaran terhadap kinerja karyawan. Hubungan pengaruh dari satu variabel searah terhadap variabel yang lainnya diilustrasikan pada gambar 2.2, berikut:



Gambar 2.2. Kerangka berpikir Penelitian

Dari gambar kerangka berpikir tersebut hubungan pengaruh masing-masing variabel dapat dibahas sebagai berikut:

1. Pengaruh Kompetensi terhadap Pembelajaran.

2. Pengaruh Tim Kerja terhadap Pembelajaran.

3. Pengaruh Kompetensi terhadap Kinerja.

4. Pengaruh Tim Kerja terhadap Kinerja.

5. Pengaruh Pembelajaran terhadap Kinerja.

C. Hipotesis Penelitian

1. Terdapat pengaruh secara positif Kompetensi terhadap Pembelajaran Karyawan di PT. Whitesky Aviation.

2. Terdapat pengaruh secara positif Tim Kerja terhadap Pembelajaran Karyawan di PT. Whitesky Aviation.

3. Terdapat pengaruh secara positif Kompetensi terhadap Kinerja Karyawan di PT. Whitesky Aviation.

4. Terdapat pengaruh secara positif Tim Kerja terhadap Kinerja Karyawan di PT. Whitesky Aviation. 
5. Terdapat pengaruh secara positif Pembelajaran terhadap Kinerja Karyawan di PT. Whitesky Aviation.

\section{METODOLOGI PENELITIAN}

\section{A. Tujuan Penelitian}

Penelitian ini secara umum bertujuan untuk mendapatkan data empirik, fakta, dan informasi yang shahih (valid) dan benar, serta dapat dipercaya (reliabel) tentang pengaruh Kompetensi, Tim Kerja, dan Pembelajaran terhadap Kinerja Karyawan di PT. Whitesky Aviation.

\section{B. Tempat dan waktu penelitian}

Penelitian dilakukan di PT. Whitesky Aviation, mulai bulan Mei sampai dengan bulan Oktober tahun 2017, meliputi kegiatan pra survei, konsolidasi, uji coba instrumen, uji validitas dan reliabilitas instrumen, serta pengumpulan dan pengolahan data hasil penelitian.

\section{Metode Penelitian}

Penelitian ini menggunakan pendekatan penelitian kuantitatif, dengan menggunakan metode survey (survey research) yaitu penelitian yang bertujuan untuk mengetahui dan menentukan kedudukan sesaat variabel (status quo variable) berdasarkan data yang ada pada saat penelitian dan hubungan antara variabel-variabel yang diteliti. Pemilihan metode ini didasarkan pada pertimbangan bahwa penelitian mencakup empat variabel dengan data berasal dari responden yang sama dan menjawab setiap pertanyaan yang diajukan secara serentak dan sekaligus.

Konstelasi hubungan dari empat variabel penelitian, yaitu fungsi kinerja, kompetensi, tim kerja dan pembelajaran, dapat diformulasikan dalam bentuk konstelasi masalah penelitian pada gambar:



Gambar 3.1. Konstelasi Masalah Penelitian

\section{Populasi dan Sampel}

Populasi penelitian ini adalah seluruh karyawan dari berbagai departemen sebanyak 200 karyawan, dalam rangka mendukung penyelenggaraan tugas pelayanan dan penerbangan.

Sampel penelitian ini adalah seluruh populasi yang terjangkau, dan berkarakter sama, yaitu sebanyak 100 karyawan dari berbagai departemen, yang diambil secara acak sederhana (Simple Random Sampling), dengan pengundian nomor responden dari seluruh karyawan di PT. Whitesky Aviation, sesuai dengan syarat penelitian.

\section{E. Teknik Pengumpulan Data}


Penelitian ini menggunakan Data primer yang dikumpulkan melalui kuesioner sebagai instrumen penelitian. Kuesioner disampaikan kepada responden yaitu karyawan di PT. Whitesky Aviation yang diteliti. Untuk melengkapi hasil kuesioner tersebut, dilakukan wawancara terhadap informan yang tidak ditentukan secara ketat, tetapi disesuaikan dengan keterkaitan data dan informasi yang dibutuhkan.

Dalam penelitian ini jenis data yang dikumpulkan adalah data faktual khusus dalam mengukur kinerja yang merupakan data kualitatif yang dikuantitatifkan, dan variabel yang diduga mempengaruhi, yaitu: kompetensi, tim kerja, dan pembelajaran.

Instrumen penelitian yang digunakan dalam penelitian ini adalah kuesioner kompetensi, tim kerja, pembelajaran, dan kinerja. Setiap instrumen dilengkapi dengan tujuan pengukuran, petunjuk pengisian dan skala penilaian. Untuk kuesioner kompetensi, tim kerja, dan pembelajaran, diisi oleh responden yaitu karyawan di PT. Whitesky Aviation, sedangkan kuesioner kinerja yang merupakan penilaian kinerja karyawan di PT. Whitesky Aviation, diisi oleh atasan responden atau pemimpin karyawan di PT. Whitesky Aviation. Untuk menghindari terjadinya salah pasangan terhadap penilaian maka diberikan kode penomoran dan nama responden. Dan masing-masing atasan karyawan di PT. Whitesky Aviation memegang nama karyawan di PT. Whitesky Aviation yang dipimpinnya dengan kode nomor responden. Seluruh instrumen yang digunakan dalam penelitian ini.

Instrumen penelitian dalam penelitian ini diuraikan berdasarkan variabel-variabel penelitian, sebagai berikut:

\section{Variabel Kinerja}

\section{a. Definisi Operasional}

Kinerja adalah hasil pekerjaan seorang karyawan di PT. Whitesky Aviation dalam pelaksanaan tugas pekerjaannya dengan indikator: 1) kualitas, 2)ketepatan waktu, 3)perilaku, 4) pencapaian tujuan, dan 5)kemampuan bekerjasama.

\section{b. Instrumen Final}

Berdasarkan hasil uji validitas dan perhitungan reliabilitas melalui SPSS 20, dan Excel, terhadap kuesioner variabel Kinerja yang terdiri dari 5 indikator dengan 25 butir pertanyaan, semua butir valid dan reliabel, maka semua butir pertanyaan dipakai dalam kuesioner penelitian. Instrumen penelitian final variabel Kinerja.

\section{Variabel Kompetensi}

\section{a. Definisi Operasional}

Kompetensi adalah kapasitas seorang karyawan di PT. Whitesky Aviation, untuk melakukan beragam tugas pekerjaan, untuk menunjukkan prestasi pada berbagai tugas dalam suatu pekerjaan, dengan indikator: 1)pengetahuan, 2) keterampilan, 3)inisiatif, 4) pemecahan masalah, dan 5) kemampuan beradaptasi. 


\section{b. Instrumen Final}

Berdasarkan hasil uji validitas dan perhitungan reliabilitas melalui SPSS 20, dan Excel, terhadap kuesioner variabel Kompetensi yang terdiri dari 5 indikator dengan 25 butir pertanyaan, semua butir valid dan reliabel, maka semua butir pertanyaan dipakai dalam kuesioner penelitian. Instrumen penelitian final variabel Kompetensi.

\section{Variabel Tim Kerja}

\section{a. Definisi Operasional}

Tim Kerja adalah Tim karyawan di PT. Whitesky Aviation, yang harus memiliki tujuan bersama, memiliki perpaduan dari keterampilan dan kemampuan yang diperlukan dan bersama-sama mempertanggung jawabkan hasil pekerjaan, dengan indikator: 1)norma, 2)koordinasi, 3)komposisi, 4) integrasi, dan 5) kontribusi.

\section{b. Instrumen Final}

Berdasarkan hasil uji validitas dan perhitungan reliabilitas melalui SPSS 20, dan Excel, terhadap kuesioner variabel Tim Kerja yang terdiri dari 5 indikator dengan 25 butir pertanyaan, semua butir valid dan reliabel, maka semua butir pertanyaan dipakai dalam kuesioner penelitian. Instrumen penelitian final variabel Tim Kerja.

\section{Variabel Pembelajaran}

\section{a. Definisi Operasional}

Pembelajaran adalah setiap perubahan perilaku karyawan di PT. Whitesky Aviation yang relatif permanen, sebagai hasil dari pengalaman secara terus menerus dalam memperoleh pengetahuan dan berbagai keterampilan untuk memahami dan menerapkannya pada seluruh proses pekerjaan, dengan indikator: 1) kreativitas, 2)pengembangan kapabilitas, 3) dorongan perubahan, 4)pembelajaran berkelanjutan, dan 5)penciptaan pengetahuan baru.

\section{b. Instrumen Final}

Berdasarkan hasil uji validitas dan perhitungan reliabilitas melalui SPSS 20, dan Excel, terhadap kuesioner variabel Pembelajaran yang terdiri dari 5 indikator dengan 25 butir pertanyaan, semua butir valid dan reliabel, maka semua butir pertanyaan dipakai dalam kuesioner penelitian.Instrumen penelitian final variabel Pembelajaran.

\section{F. Teknik Analisis Data}

Untuk keperluan menganalisis data yang telah dikumpulkan, digunakan teknik analisis data secara deskriptif dan inferensial. Penggunaan teknik analisis data secara deskriptif untuk memperoleh gambaran karakteristik penyebaran nilai setiap variabel yang diteliti. Analisis deskriptif digunakan dalam hal penyajian data, ukuran sentral, dan ukuran penyebaran. Penyajian data menggunakan daftar distribusi dan histogram. Ukuran sentral meliputi mean, median, dan modus. Ukuran penyebaran meliputi varians dan simpangan baku. Sedangkan analisis inferensial 
digunakan untuk menguji hipotesis dengan menggunakan analisis jalur (path analysis) model trimming. Semua pengujian hipotesis dengan menggunakan $\alpha=0.05$. Sebelum dilakukan pengujian hipotesis, terlebih dahulu dilakukan uji normalitas galat taksiran regresi dengan menggunakan teknik Liliefors, dan uji homogenitas varians dengan menggunakan teknik Uji Barlett.

Untuk menghitung pengaruh langsung dan tidak langsung dari variabel bebas terhadap suatu variabel terikat, tercermin dari koefisien jalur. Sedangkan untuk menentukan koefisien jalur diperlukan persyaratan sebagai berikut: 1) hubungan antara tiap dua variabel harus merupakan hubungan yang linier, aditif dan kausal; 2)sistem menganut prinsip rekursif (eka arah); 3) semua variabel residu tidak saling berkorelasi dan juga tidak berkorelasi dengan variabel penyebab; dan 4) data masing-masing variabel adalah kontinum.

Pada model analisis jalur dikenal dua tipe variabel yaitu: variabel eksogen dan variabel endogen. Variabel eksogen memberikan pengaruh, baik langsung maupun tidak langsung terhadap variabel endogen. Sedangkan variabel endogen merupakan variabel yang dapat mempengaruhi variabel endogen lainnya.

Sesuai dengan kerangka berpikir yang dibuat, maka variabel endogen dalam penelitian ini adalah kinerja $(\mathrm{Y})$. Sedangkan variabel eksogen terdiri dari: kompetensi
$\left(\mathrm{X}_{1}\right)$, tim kerja $\left(\mathrm{X}_{2}\right)$ dan pembelajaran $\left(\mathrm{X}_{3}\right)$.

Namun demikian pembelajaran $\left(\mathrm{X}_{3}\right)$ merupakan variabel endogen bagi variabel kompetensi $\left(\mathrm{X}_{1}\right)$, dan tim kerja $\left(\mathrm{X}_{2}\right)$.

\section{G. Hipotesis Statistik}

Hipotesis statistik terdiri dari 5:

1. Hipotesis Statistik 1

$H_{0}: \rho_{31}=0 \quad H_{1}: \rho_{31}>0$

2. Hipotesis Statistik 2

$H_{0}: \rho_{32}=0 \quad H_{1}: \rho_{32}>0$

3. Hipotesis Statistik 3

$\mathrm{H}_{0}: \rho_{\mathrm{Y} 1}=0 \quad \mathrm{H}_{1}: \rho_{\mathrm{Y} 1}>0$

4. Hipotesis Statistik 4

$\mathrm{H}_{0}: \rho_{\mathrm{Y} 2}=0 \quad \mathrm{H}_{1}: \rho_{\mathrm{Y} 2}>0$

5. Hipotesis Statistik 5

$\mathrm{H}_{0}: \rho_{\mathrm{Y} 3}=0 \quad \mathrm{H}_{1}: \rho_{\mathrm{Y} 3}>0$

Keterangan:

$\mathrm{H}_{0}$ : Hipotesis nol

$\mathrm{H}_{1}$ : Hipotesis alternatif

$\rho_{31}$ : Koefisien Jalur (rho) untuk populasi tentang pengaruh Kompetensi $\left(\mathrm{X}_{1}\right)$ terhadap Pembelajaran $\left(\mathrm{X}_{3}\right)$

$\rho_{32}$ : Koefisien Jalur (rho) untuk populasi tentang pengaruh Tim Kerja $\left(\mathrm{X}_{2}\right)$ terhadap Pembelajaran $\left(\mathrm{X}_{3}\right)$

$\rho_{\mathrm{Y} 1}$ : Koefisien Jalur (rho) untuk populasi tentang pengaruh Kompetensi $\left(\mathrm{X}_{1}\right)$ terhadap Kinerja (Y)

$\rho_{\mathrm{Y} 2}$ : Koefisien Jalur (rho) untuk populasi tentang pengaruh Tim Kerja $\left(\mathrm{X}_{2}\right)$ terhadap Kinerja (Y)

$\rho_{\text {Y3 }}$ : Koefisien Jalur (rho) untuk populasi tentang pengaruh Pembelajaran $\left(\mathrm{X}_{3}\right)$ terhadap Kinerja (Y) 


\section{HASIL PENELITIAN DAN PEMBAHASAN}

\section{A. Deskripsi Data}

Deskripsi data penelitian dimaksudkan untuk memberikan gambaran tentang perolehan data hasil penyebaran instrumen penelitian melalui kuesioner. Dalam mendeskripsikan data digunakan perhitungan statistik deskriptif, yaitu meliputi skor minimal, skor maksimal, jangkauan, rata-rata, nilai tengah, median, simpangan baku, dan varians. Deskripsi data dilengkapi dengan tabel distribusi frekuensi dan histogram.

\section{Variabel Kinerja}

Distribusi frekuensi dapat digambarkan dalam bentuk histogram sebagai berikut:



Gambar 4.1. Diagram sebaran skor data Kinerja

\section{Variabel Kompetensi}

Distribusi frekuensi dapat digambarkan dalam bentuk histogram sebagai berikut:



Gambar 4.2.Diagram sebaran skor data Kompetensi

\section{Variabel Tim Kerja}

Distribusi frekuensi dapat digambarkan dalam bentuk histogram sebagai berikut:

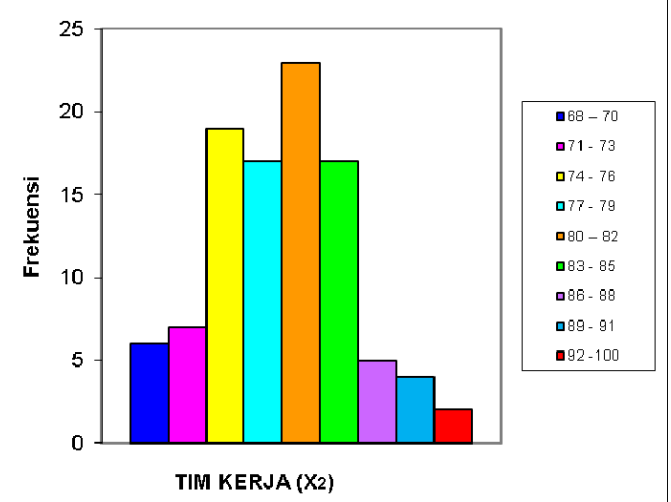

Gambar 4.3.Diagram sebaran skor data Tim Kerja

\section{Variabel Pembelajaran}

Distribusi frekuensi dapat digambarkan dalam bentuk histogram sebagai berikut:

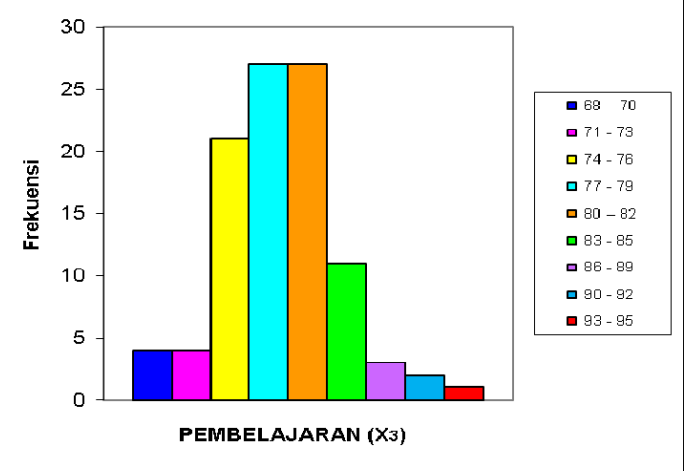

Gambar 4.4. Diagram sebaran skor data Pembelajaran 
Deskripsi data penelitian yang dihasilkan untuk semua variabel dalam penelitian ini, meliputi: Kinerja (Y), Kompetensi $\left(\mathrm{X}_{1}\right)$, Tim Kerja $\left(\mathrm{X}_{2}\right)$, dan Pembelajaran $\left(\mathrm{X}_{3}\right)$, disajikan pada table 4.1, berikut ini:
Tabel 4.1. Ringkasan Deskripsi Data 4 variabel Statistics

\begin{tabular}{|c|c|c|c|c|}
\hline & $\bar{Y}$ & $X_{1}$ & $X_{2}$ & $X_{3}$ \\
\hline Valid & 100 & 100 & 100 & 100 \\
\hline Missing & $\mathbf{0}$ & 0 & $\mathbf{0}$ & 0 \\
\hline Mean & 80.80 & 79.74 & 79.47 & 79.13 \\
\hline Median & 81.00 & 79.00 & 80.00 & 79.00 \\
\hline Mode & 82 & $75^{a}$ & $76^{a}$ & 82 \\
\hline $\begin{array}{l}\text { Std. } \\
\text { Deviation }\end{array}$ & 5.382 & 6.690 & 5.672 & 4.620 \\
\hline Variance & 28.970 & 44.760 & 32.171 & 21.347 \\
\hline Skewness & .019 & .284 & .397 & .441 \\
\hline Kurtosis & .805 & .140 & .939 & 1.061 \\
\hline Range & 31 & 36 & 32 & 27 \\
\hline Minimum & 63 & 62 & 68 & 68 \\
\hline Maximum & 94 & 98 & 100 & 95 \\
\hline Sum & 8080 & 7974 & 7947 & 7913 \\
\hline
\end{tabular}

a. Multiple modes exist. The smallest value is shown

\section{B. Pengujian Persyaratan Analisis}

Pengujian Persyaratan dalam penelitian, meliputi: 1) Uji Normalitas, 2) Uji Homogenitas, dan 3) Uji Linieritas. Pengujian untuk masing-masing tersebut diatas, disajikan sebagai berikut:

\section{Uji Normalitas}

Uji Normalitas setiap variabel menggunakan SPSS 20 dengan menggunakan Kolmogorov-Smirnov Test. Hasil uji normalitas variabel Kinerja, Kompetensi, Tim Kerja, dan Pembelajaran, dalam penelitian ini disajikan pada tabel 4.2.

Tabel 4.2. Hasil Uji Normalitas 4 variabel

Tests of Normality

\begin{tabular}{|l|r|c|c|r|r|r|}
\hline & \multicolumn{4}{|c|}{ Kolmogorov-Smirnov } & \multicolumn{3}{|c|}{ Shapiro-Wilk } \\
\cline { 2 - 7 } & Statistic & \multicolumn{1}{c|}{ df } & \multicolumn{1}{c|}{ Sig. } & Statistic & \multicolumn{1}{c|}{ df } & \multicolumn{1}{c|}{ Sig. } \\
\hline Y & .092 & $\mathbf{1 0 0}$ & .035 & .968 & 100 & .016 \\
$X_{1}$ & .094 & $\mathbf{1 0 0}$ & .029 & .971 & 100 & .027 \\
$X_{2}$ & .094 & 100 & .029 & .962 & 100 & .006 \\
$X_{3}$ & .090 & 100 & .044 & .965 & 100 & .009 \\
\hline
\end{tabular}

a. Lilliefors Significance Correction

Uji Normalitas ke-empat variabel tersebut menunjukkan bahwa data tersebar secara normal. Hal ini dapat ditunjukkan dari nilai signifikansi yang diperoleh seluruhnya lebih kecil dari 0.05 .

Berdasarkan pada hasil tersebut dapat disimpulkan bahwa ke-empat variabel tersebut telah memenuhi kriteria uji Normalitas.

\section{Uji Homogenitas}

Uji Homogenitas regresi antar variabel dilakukan dengan SPSS 20, dengan hasil, sebagai berikut:

a. Uji Homogenitas Kompetensi terhadap Pembelajaran

Test of Homogeneity of Variances KOMPETENSI - PEMBELAJARAN

\begin{tabular}{|r|r|r|r|}
\hline Levene Statistic & \multicolumn{1}{|c|}{ df1 } & \multicolumn{1}{c|}{ df2 } & Sig. \\
\hline 4.262 & 17 & 73 & $\mathbf{. 0 0 0}$ \\
\hline
\end{tabular}

b. Uji Homogenitas Tim Kerja terhadap Pembelajaran

Test of Homogeneity of Variances TIM_KERJA - PEMBELAJARAN

\begin{tabular}{|l|l|l|l|}
\hline Levene Statistic & df1 & df2 & Sig. \\
\hline
\end{tabular}




\begin{tabular}{|r|r|r|r|}
\hline 7.081 & 16 & 73 & $\mathbf{. 0 0 0}$ \\
\hline
\end{tabular}

c. Uji Homogenitas Kompetensi terhadap Kinerja

Test of Homogeneity of Variances KOMPETENSI - KINERJA

\begin{tabular}{|r|r|r|r|}
\hline Levene Statistic & \multicolumn{1}{c|}{ df1 } & \multicolumn{1}{c|}{ df2 } & Sig. \\
\hline 3.109 & 17 & 73 & $\mathbf{. 0 0 0}$ \\
\hline
\end{tabular}

d. Uji Homogenitas Tim Kerja terhadap Kinerja

Test of Homogeneity of Variances TIM_KERJA - KINERJA

\begin{tabular}{|r|r|r|r|}
\hline Levene Statistic & df1 & df2 & Sig. \\
\hline 3.835 & 16 & 73 & $\mathbf{. 0 0 0}$ \\
\hline
\end{tabular}

e. Uji Homogenitas Pembelajaran terhadap Kinerja

Test of Homogeneity of Variances PEMBELAJARAN - KINERJA

\begin{tabular}{|l|l|l|l|}
\hline Levene Statistic & df1 & df2 & Sig. \\
\hline
\end{tabular}

\begin{tabular}{|r|r|r|r|}
\hline 3.886 & 16 & 74 & $\mathbf{. 0 0 0}$ \\
\hline
\end{tabular}

Uji Homogenitas Varians ke-empat variabel, Kompetensi, Tim Kerja, dan Pembelajaran terhadap variabel Kinerja tidak signifikan, karena adanya Homogenitas. Ini ditunjukkan dengan nilai signifikansi lebih kecil dari 0.05 , sehingga skor-skor pada variabel Kompetensi, Tim Kerja, Pembelajaran dan skor-skor pada variabel Kinerja menyebar secara homogen, berarti telah memenuhi kriteria uji Homogenitas.

\section{Uji Linieritas}

Uji Linieritas antar variabel dengan proses ANOVA berdasarkan SPSS 20, jika nilai Linearity < nilai $\alpha(\mathbf{0 . 0 5})$, maka distribusi berpola linier.

Hasil Uji Linieritas, sebagai berikut:

a. Uji Linieritas Kompetensi terhadap Pembelajaran $=\mathbf{0 , 0 0 0}$ b. Uji Linieritas Tim Kerja terhadap Pembelajaran $=\mathbf{0 , 0 0 0}$

c. Uji Linieritas Kompetensi terhadap Kinerja $=\mathbf{0 , 0 0 0}$

d. Uji Linieritas Tim Kerja terhadap Kinerja $=\mathbf{0 , 0 0 0}$

e. Uji Linieritas Pembelajaran terhadap Kinerja $=\mathbf{0 , 0 0 0}$

\section{Pengujian Model}

Sebelum dilakukan perhitungan untuk menguji model kausalitas dengan menggunakan metode analisis jalur, maka diperlukan data hasil penelitian yang telah diuji dan memenuhi seluruh persyaratan. Salah satu persyaratan yang penting dan harus dipenuhi adalah adanya korelasi yang signifikan antara variabel-variabel yang terkait. Korelasi antar variabel tersebut dihitung dengan koefisien korelasi.

Berikut ini merupakan langkah-langkah dalam pengujian model, yaitu

\section{Model Struktural dan Matriks Korelasi antar Variabel}

Model struktural dalam penelitian ini disajikan pada gambar 4.5

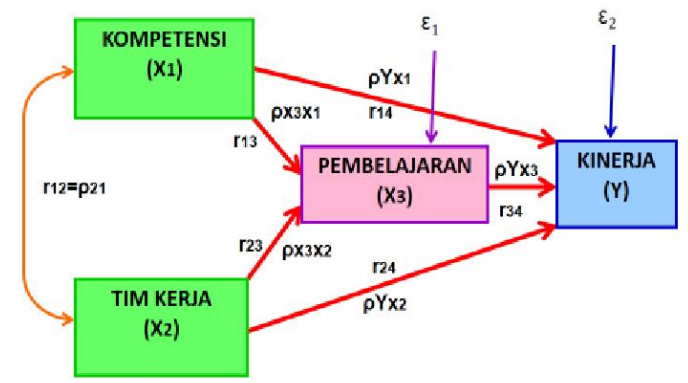

Gambar 4.5. Hubungan kausal; $X_{1}, X_{2}$, dan $X_{3}$ terhadap Y 
Tabel 4.3. Matriks Korelasi antar Variabel

\begin{tabular}{|c|c|c|c|c|c|}
\hline \multicolumn{6}{|c|}{ Correlations } \\
\hline & & (Y) & $\left(\mathbf{X}_{1}\right)$ & $\left(\mathbf{X}_{2}\right)$ & $\left(\mathbf{X}_{3}\right)$ \\
\hline & tion & 1 & $.986^{* *}$ & $.992^{* *}$ & $.994^{* *}$ \\
\hline & Sig. (2-tailed) & & .000 & .000 & .000 \\
\hline & $\mathbf{N}$ & 100 & 100 & 100 & 100 \\
\hline KM & $\begin{array}{l}\text { Pearson } \\
\text { Correlation }\end{array}$ & $.986^{* *}$ & 1 & $.994^{* *}$ & $.989^{* *}$ \\
\hline$\left(\mathrm{X}_{1}\right)$ & Sig. (2- & .000 & & .000 & .000 \\
\hline TIM & $\begin{array}{l}\text { Pear } \\
\text { Corr }\end{array}$ & $.992^{* *}$ & $.994^{* * *}$ & $\begin{array}{r}100 \\
1\end{array}$ & $.996^{\text {** }}$ \\
\hline$\left(\mathrm{X}_{2}\right)$ & $\begin{array}{l}\text { Sig. (2-tailed) } \\
\text { N }\end{array}$ & $\begin{array}{r}.000 \\
100\end{array}$ & $\begin{array}{r}.000 \\
100\end{array}$ & 100 & $\begin{array}{r}.000 \\
100\end{array}$ \\
\hline & $\begin{array}{l}\text { Pearson } \\
\text { Correlation }\end{array}$ & $.994^{* *}$ & $.989^{* *}$ & .996 ** & 1 \\
\hline$\left.X_{3}\right)$ & Sig. ( & .000 & .000 & .000 & \\
\hline & $\mathbf{N}$ & 10 & 100 & 100 & 100 \\
\hline
\end{tabular}

$* *$. Correlation is significant at the 0.01 level (2-tailed).

Dari tabel 4.3., dapat diketahui bahwa: koefisien korelasi antar variabel $\mathrm{X}_{1}$ dan $\mathrm{X}_{2}$ adalah $r_{12}=0.994$, koefisien korelasi antar variabel $X_{1}$ dan $X_{3}$ adalah $r_{13}=0.989$, koefisien korelasi antar variabel $\mathrm{X}_{2}$ dan $\mathrm{X}_{3}$ adalah $\mathrm{r}_{23}=0.996$, koefisien korelasi antar variabel $\mathrm{X}_{1}$ dan $\mathrm{Y}\left(\mathrm{X}_{4}\right)$ adalah $\mathrm{r}_{14}=0.986$, koefisien korelasi antar variabel $\mathrm{X}_{2}$ dan $\mathrm{Y}\left(\mathrm{X}_{4}\right)$ adalah $\mathrm{r}_{24}=0.992$, koefisien korelasi antar variabel $\mathrm{X}_{3}$ dan $\mathrm{Y}\left(\mathrm{X}_{4}\right)$ adalah $\mathrm{r}_{34}=0.994$

\section{Perhitungan Koefisien Jalur pada Sub-Struktur}

Model struktural yang ditampilkan pada gambar 4.5, terdiri dari dua sub-struktur, yaitu Sub-Struktur-1 dan Sub-Struktur-2.

\section{Perhitungan Koefisien Jalur pada Sub-Struktur 1}

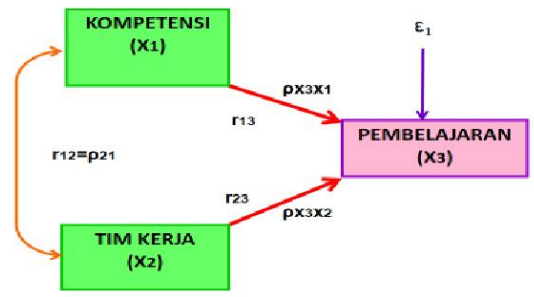

Gambar 4.6. Hubungan kausal: Sub-Struktur 1
Hubungan kausal antar variabel pada Sub-Struktur-1, yang ditampilkan pada gambar 4.6, terdiri dari satu variabel endogen $X_{3}$, dan dua variabel eksogen: $X_{1}$, dan $\mathrm{X}_{2}$.

Persamaan struktural untuk sub-struktur1 adalah, $X_{3}=\rho x_{3} X_{1} X_{1}+\rho x_{3} X_{2} X_{2}+\varepsilon_{1}$.

Hasil pengolahan data dengan SPSS 20, disajikan pada tabel 4.4 , tabel 4.5 dan tabel 4.6., sebagai berikut:

Model 1: Koefisien $X_{1}$,dan $\mathbf{X}_{\mathbf{2}}$, terhadap Pembelajaran $\left(\mathbf{X}_{3}\right)$ Tabel 4.4. Coefficients Model 1 - Sub-Struktur-1 Coefficients $^{\mathrm{a}}$

\begin{tabular}{|l|r|r|r|r|r|}
\hline Model & \multicolumn{2}{|c|}{$\begin{array}{c}\text { Unstandardized } \\
\text { Coefficients }\end{array}$} & $\begin{array}{c}\text { Standardized } \\
\text { Coefficients }\end{array}$ & \multirow{2}{*}{ Sig. } \\
\cline { 2 - 4 } & \multicolumn{1}{c|}{ B } & \multicolumn{1}{c|}{$\begin{array}{c}\text { Std. } \\
\text { Error }\end{array}$} & Beta & & \\
\hline (Constant) & 13.482 & 3.526 & & 3.824 & .000 \\
1 KOMPETENSI & .224 & .084 & .254 & 2.677 & .009 \\
TIM_KERJA & .604 & .087 & .656 & 6.907 & .000 \\
\hline
\end{tabular}

a. Dependent Variable: PEMBELAJARAN

Model 1: Anova $X_{1}$, dan $X_{2}$, terhadap Pembelajaran $\left(X_{3}\right)$

Tabel 4.5. ANOVA Model 1 - Sub-Struktur-1 ANOVA $^{\mathrm{a}}$

\begin{tabular}{|c|c|c|c|c|c|}
\hline Model & $\begin{array}{c}\text { Sum of } \\
\text { Squares }\end{array}$ & df & $\begin{array}{c}\text { Mean } \\
\text { Square }\end{array}$ & $\mathbf{F}$ & Sig. \\
\hline $\begin{array}{ll}\text { Regression } \\
1 & \begin{array}{l}\text { Residual } \\
\text { Total }\end{array} \\
\end{array}$ & $\begin{array}{r}2226.871 \\
607.369 \\
2834.240\end{array}$ & $\begin{array}{r}2 \\
97 \\
99\end{array}$ & $\begin{array}{r}1113.436 \\
6.262\end{array}$ & 177.822 & $.000^{b}$ \\
\hline
\end{tabular}

b. Predictors: (Constant), TIM_KERJA, KOMPETENSI

Model 1: Summary $X_{1}$ dan $X_{2}$, terhadap Pembelajaran $\left(X_{3}\right)$ Tabel 4.6. Model Summary Model 1 - Sub-Struktur-1 Model Summary ${ }^{b}$

\begin{tabular}{|l|c|r|r|r|}
\hline Model & R & $\begin{array}{c}\text { R } \\
\text { Square }\end{array}$ & $\begin{array}{c}\text { Adjusted } \\
\text { R Square }\end{array}$ & $\begin{array}{c}\text { Std. Error of } \\
\text { the Estimate }\end{array}$ \\
\hline 1 &. $\mathbf{8 8 6}^{\mathrm{a}}$ & .786 & .781 & $\mathbf{2 . 5 0 2}$ \\
\hline
\end{tabular}

a. Predictors: (Constant), TIM_KERJA, KOMPETENSI b. Dependent Variable: PEMBELAJARAN

\section{Perhitungan Besar Pengaruh pada Sub-Struktur-1}

Untuk mengetahui besarnya pengaruh yang diterima oleh sebuah variabel endogen dari dua variabel eksogen, dapat secara parsial maupun bersama-sama. Pengaruh secara parsial berupa pengaruh langsung, maupun pengaruh tidak langsung, yaitu melalui variabel eksogen yang lain. 
a. Menghitung pengaruh langsung, pengaruh tidak langsung, serta pengaruh total variabel Kompetensi $\left(\mathrm{X}_{1}\right)$ terhadap variabel Pembelajaran $\left(\mathrm{X}_{3}\right)$ secara parsial bersama variabel Tim Kerja $\left(\mathrm{X}_{2}\right)$ :

1) Besarnya pengaruh langsung variabel $\left(\mathrm{X}_{1}\right)$ terhadap variabel $\left(\mathrm{X}_{3}\right)=\rho \mathrm{x}_{3} \mathrm{X}_{1} \mathrm{X}$ $\rho \mathrm{x}_{3} \mathrm{x}_{1}=0.254 \mathrm{x} 0.254=0.0645=6,45 \%$

2) Besarnya pengaruh tidak langsung variabel $\left(\mathrm{X}_{1}\right)$ terhadap variabel $\left(\mathrm{X}_{3}\right)$, melalui variabel Tim Kerja $\left(\mathrm{X}_{2}\right)$

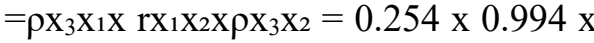
$0.656=0.1656=16,56 \%$

3) Besarnya pengaruh total variabel $X_{1}$ terhadap variabel $\mathrm{X}_{3}$ melalui variabel Tim Kerja $\left(\mathrm{X}_{2}\right),=\left[\rho \mathrm{x}_{3} \mathrm{x}_{1} \mathrm{x}_{\rho} \mathrm{x}_{3} \mathrm{x}_{1}\right]+$ $\left[\rho \mathrm{x}_{3} \mathrm{X}_{1} \mathrm{xrx}_{1} \mathrm{X}_{2} \mathrm{X}_{\rho} \mathrm{x}_{3} \mathrm{x}_{2}\right]=0.0645+0.1656$ $=0.2301=23,01 \%$

Kesimpulan : pengaruh variabel Kompetensi $\left(\mathrm{X}_{1}\right) \quad$ terhadap variabel Pembelajaran $\left(X_{3}\right)$ adalah sebesar $23,01 \%$ hal ini berarti Pembelajaran ditentukan oleh Kompetensi sebesar 23,01\%.

b. Menghitung pengaruh langsung, pengaruh tidak langsung, serta pengaruh total variabel Tim Kerja $\left(\mathrm{X}_{2}\right)$ terhadap variabel Pembelajaran $\left(\mathrm{X}_{3}\right)$ secara parsial bersama variabel Kompetensi $\left(\mathrm{X}_{1}\right)$ : Kesimpulan : pengaruh variabel Tim Kerja $\left(\mathrm{X}_{2}\right)$ terhadap variabel Pembelajaran $\left(\mathrm{X}_{3}\right)$ adalah sebesar $\mathbf{5 9 , 5 9 \%}$, hal ini berarti Pembelajaran ditentukan oleh Tim Kerja sebesar $59,59 \%$.

\section{Perhitungan Koefisien Jalur pada Sub-} Struktur-2



Gambar 4.7. Hubungan kausal: Sub-Struktur 2

Hubungan kausal antar variabel pada Sub-Struktur-2, yang ditampilkan pada gambar 4.7, terdiri dari 1 variabel endogen yaitu Kinerja (Y) dan 3 variabel eksogen yaitu: 1) Kompetensi $\left.\left(\mathrm{X}_{1}\right), 2\right)$ Tim Kerja $\left(\mathrm{X}_{2}\right)$, dan 3) Pembelajaran $\left(\mathrm{X}_{3}\right)$,

Persamaan struktural sub-struktur-2 adalah: $Y=\rho Y x_{1} X_{1}+\rho Y x_{2} X_{2}+\rho Y x_{3} X_{3}+\varepsilon_{2}$

Hasil pengolahan data dengan SPSS 20, disajikan pada tabel 4.7 , tabel 4.8 dan tabel 4.9., sebagai berikut:

Model 1: Koefisien $\mathrm{X}_{1}, \mathrm{X}_{2}, \& \mathrm{X}_{3}$ terhadap Kinerja (Y)

Tabel 4.7. Coefficients Model 1 - Sub-Struktur-2 Coefficients ${ }^{\mathrm{a}}$

\begin{tabular}{|l|r|r|r|r|r|}
\hline \multirow{2}{*}{ Model } & \multicolumn{2}{|c|}{$\begin{array}{c}\text { Unstandardized } \\
\text { Coefficients }\end{array}$} & $\begin{array}{c}\text { Standardized } \\
\text { Coefficients }\end{array}$ & \multirow{2}{*}{ Sig. } \\
\cline { 2 - 4 } & \multicolumn{1}{|c|}{$\mathrm{B}$} & $\begin{array}{c}\text { Std. } \\
\text { Error }\end{array}$ & Beta & & \\
\hline (Constant) & 3.482 & 3.099 & & 1.124 & .264 \\
KOMPETENSI & .181 & .071 & .192 & 2.560 & .012 \\
1 & .605 & .087 & .611 & 6.913 & .000 \\
PIM_KERJA & .605 & .083 & .168 & 2.174 & .032 \\
\hline
\end{tabular}

a. Dependent Variable: KINERJA

Model 1: ANOVA $\mathrm{X}_{1}, \mathrm{X}_{2}, \& \mathrm{X}_{3}$ terhadap Kinerja (Y) Tabel 4.8. ANOVA Model 1 Sub-Struktur-2

\begin{tabular}{|c|c|c|c|c|c|}
\hline Model & $\begin{array}{c}\text { Sum of } \\
\text { Squares }\end{array}$ & df & $\begin{array}{c}\text { Mean } \\
\text { Square }\end{array}$ & $\bar{F}$ & Sig. \\
\hline Regression & 2873.060 & 3 & 957.687 & 227.851 & $.000^{b}$ \\
\hline 1 Residual & 403.500 & 96 & 4.203 & & \\
\hline Total & 3276.560 & 99 & & & \\
\hline
\end{tabular}


Tabel 4.9. Model Summary Model 1 Sub-Struktur-2 Model Summary ${ }^{\mathrm{b}}$

\begin{tabular}{l|c|r|r|r|}
\hline Model & R & $\begin{array}{c}\text { R } \\
\text { Square }\end{array}$ & $\begin{array}{c}\text { Adjusted } \\
\text { R Square }\end{array}$ & $\begin{array}{r}\text { Std. Error of } \\
\text { the Estimate }\end{array}$ \\
\hline 1 & .936 & .877 & .873 & $\mathbf{2 . 0 5 0}$ \\
\hline
\end{tabular}
a. Predictors: (Constant), PEMBELAJARAN,
KOMPETENSI, TIM_KERJA
b. Dependent Variable: KINERJA

6. Perhitungan Besar Pengaruh pada SubStruktur 2

Untuk mengetahui besarnya pengaruh yang diterima oleh sebuah variabel endogen dari tiga variabel eksogen, dapat secara parsial maupun bersama-sama. Pengaruh secara parsial berupa pengaruh langsung, maupun pengaruh tidak langsung, yaitu melalui variabel eksogen yang lain.

a. Menghitung pengaruh langsung, pengaruh tidak langsung, serta pengaruh total variabel Kompetensi $\left(\mathrm{X}_{1}\right)$ terhadap variabel Kinerja (Y) secara parsial bersama variabel Tim Kerja $\left(\mathrm{X}_{2}\right)$, dan variabel Pembelajaran $\left(\mathrm{X}_{3}\right)$ :

1) Besarnya pengaruh langsung variabel $\left(\mathrm{X}_{1}\right)$ terhadap variabel $(\mathrm{Y})=\rho_{\mathrm{Y}} \mathrm{X}_{1} \mathrm{X}$ $\rho \mathrm{Yx}_{1}=0.192 \mathrm{x} 0.192=0.0369=3,69 \%$

2) Besarnya pengaruh tidak langsung variabel $\left(\mathrm{X}_{1}\right)$ terhadap variabel $(\mathrm{Y})$, melalui variabel Tim Kerja $\left(\mathrm{X}_{2}\right)$ $=\rho \mathrm{Yx}_{1} \mathrm{x} \operatorname{rx}_{1} \mathrm{x}_{2} \mathrm{x} \rho \mathrm{Yx}_{2}=0.192 \times 0.994 \mathrm{x}$ $0.611=0.1166=11,66 \%$

3) Besarnya pengaruh tidak langsung variabel $\left(\mathrm{X}_{1}\right)$ terhadap variabel $(\mathrm{Y})$, melalui variabel Pembelajaran $\left(\mathrm{X}_{3}\right)$ $=\rho_{\mathrm{Y}} \mathrm{X}_{1} \mathrm{X} \mathrm{rx}_{1} \mathrm{X}_{3} \mathrm{X} \rho \mathrm{Yx}_{3}=0.192 \times 0.989 \mathrm{x}$ $0.168=0.0319=3,19 \%$

4) Besarnya pengaruh total variabel $X_{1}$ terhadap variabel $\mathrm{Y}$ melalui variabel
Tim Kerja $\left(\mathrm{X}_{2}\right)$, dan Pembelajaran $\left(X_{3}\right)=\left[\rho Y_{1} x \rho Y x_{1}\right]+\left[\rho Y x_{1} x \operatorname{rx}_{1} x_{2} x\right.$ $\left.\rho \mathrm{Yx}_{2}\right]+\left[\rho \mathrm{Yx}_{1} \mathrm{xrx}_{1} \mathrm{x}_{3} \mathrm{x} \rho \mathrm{Yx}_{3}\right]=0.0369$ $+0.1166+0.0319=0.1854=18,54 \%$

Kesimpulan: pengaruh variabel Kompetensi ( $\left.\mathrm{X}_{1}\right)$ terhadap variabel Kinerja (Y) adalah sebesar $18,54 \%$, hal ini berarti Kinerja ditentukan oleh Kompetensi sebesar 18,54\%.

b.Menghitung pengaruh langsung, pengaruh tidak langsung, serta pengaruh total variabel Tim Kerja $\left(\mathrm{X}_{2}\right)$ terhadap variabel Kinerja (Y) secara parsial bersama variabel Kompetensi $\left(\mathrm{X}_{1}\right), \quad$ dan Pembelajaran $\left(\mathrm{X}_{3}\right)$ :Kesimpulan: pengaruh variabel Tim Kerja $\left(\mathrm{X}_{2}\right)$ terhadap variabel Kinerja (Y) adalah sebesar 59,22\%, hal ini berarti Kinerja ditentukan oleh Tim Kerja sebesar 59,22\%.

c. Menghitung pengaruh langsung, pengaruh tidak langsung, serta pengaruh total variabel Pembelajaran $\left(X_{3}\right)$ terhadap variabel Kinerja (Y) secara parsial bersama variabel Kompetensi $\left(\mathrm{X}_{1}\right)$, dan Tim Kerja $\left(\mathrm{X}_{2}\right)$ : Kesimpulan: pengaruh variabel Pembelajaran $\left(\mathrm{X}_{3}\right)$ terhadap variabel Kinerja (Y) adalah sebesar 16,24\%, hal ini berarti Kinerja ditentukan oleh Pembelajaran sebesar 16,24\%.

\section{Kesimpulan Pengujian Hipotesis}

Dari kesimpulan yang diperoleh dapat dikomparasikan dengan hipotesis yang diajukan dalam penelitian ini. Dari Lima hipotesis yang diajukan, berdasarkan hasil 
penelitian, seluruh hipotesis null $\left(\mathrm{H}_{0}\right)$ ditolak, menerima hipotesis alternatif $\left(\mathrm{H}_{1}\right)$.

\section{1). Hipotesis Pertama}

Hipotesis null $\left(\mathrm{H}_{0}\right)$ ditolak berdasarkan uji keberartian koefisien jalur, nilai hitung $\rho$ untuk variabel Kompetensi $\left(\mathrm{X}_{1}\right)=0.009$ atau $0.009<0.05$. Hal ini berarti secara parsial terdapat pengaruh secara signifikan antara Kompetensi $\left(\mathrm{X}_{1}\right)$ terhadap Pembelajaran $\left(\mathrm{X}_{3}\right)$. Hipotesis satu $\left(\mathrm{H}_{1}\right)$ diterima yaitu: "Terdapat pengaruh Kompetensi terhadap Pembelajaran". Besar pengaruh Kompetensi terhadap Pembelajaran sebesar 23,01\%.

2) Hipotesis Kedua: Terdapat pengaruh secara positif dan signifikan $(0.000<0.05)$ variabel Tim Kerja terhadap variabel Pembelajaran, sebesar 59,59\%.

3) Hipotesis Ketiga: Terdapat pengaruh secara positif dan signifikan $(0.012<0.05)$ variabel Kompetensi terhadap variabel Kinerja, sebesar $18,54 \%$.

4) Hipotesis Keempat: Terdapat pengaruh secara positif dan signifikan $(0.000<0.05)$ variabel Tim Kerja terhadap variabel Kinerja, sebesar 59,22\%.

5) Hipotesis Kelima: Terdapat pengaruh secara positif dan signifikan $(0.032<0.05)$ variabel Pembelajaran terhadap variabel Kinerja, sebesar 16,24\%.

\section{E. Keterbatasan Penelitian}

Penelitian dengan judul pengaruh Kompetensi, Tim Kerja, dan Pembelajaran terhadap Kinerja Karyawan di PT. Whitesky
Aviation ini, berfokus pada pengujian pengaruh langsung antar variabel dalam hubungan kausal yang disajikan dengan sebuah jalur kausalistik. Untuk keperluan ini digunakan analisis jalur dengan dibantu software SPSS 20.0. Namun demikian penelitian ini tidak terlepas dari keterbatasan yang dapat mengakibatkan adanya keterbatasan-keterbatasan pada pengukuran variabel secara akurat, dan masih adanya keterbatasan lain yang mungkin ikut menentukan variabel kinerja, namun tidak diteliti di dalam penelitian ini.

\section{KESIMPULAN, dan IMPLIKASI}

\section{A. KESIMPULAN}

Berdasarkan hasil analisis data dan pembahasan hasil penelitian, maka temuan penelitian disimpulkan sebagai berikut:

1. Terdapat pengaruh secara positif dan signifikan Kompetensi terhadap Pembelajaran karyawan di PT. Whitesky Aviation. Temuan ini dapat diartikan bahwa tinggi rendahnya kualitas Pembelajaran, salah satunya dipengaruhi oleh Kompetensi, sehingga jika kualitas Kompetensi ditingkatkan, akan dapat meningkatkan kualitas Pembelajaran.

2. Terdapat pengaruh secara positif dan signifikan Tim Kerja terhadap Pembelajaran karyawan di PT. Whitesky Aviation. Temuan ini dapat diartikan bahwa tinggi rendahnya kualitas Pembelajaran, salah satunya dipengaruhi oleh Tim Kerja, sehingga jika kualitas 
Tim Kerja ditingkatkan, akan dapat meningkatkan kualitas Pembelajaran.

3. Terdapat pengaruh secara positif dan signifikan Kompetensi terhadap Kinerja karyawan di PT. Whitesky Aviation. Temuan ini dapat diartikan bahwa tinggi rendahnya kualitas Kinerja, salah satunya dipengaruhi oleh Kompetensi, sehingga jika kualitas Kompetensi ditingkatkan, akan dapat meningkatkan kualitas Kinerja.

4. Terdapat pengaruh secara positif dan signifikan Tim Kerja terhadap Kinerja karyawan di PT. Whitesky Aviation. Temuan ini dapat diartikan bahwa tinggi rendahnya kualitas Kinerja, salah satunya dipengaruhi oleh Tim Kerja, sehingga jika kualitas Tim Kerja ditingkatkan, akan dapat meningkatkan kualitas Kinerja.

5. Terdapat pengaruh secara positif dan signifikan Pembelajaran terhadap karyawan di PT. Whitesky Aviation. Temuan ini dapat diartikan bahwa tinggi rendahnya kualitas Kinerja, salah satunya dipengaruhi oleh Pembelajaran, sehingga jika kualitas Pembelajaran ditingkatkan, akan dapat meningkatkan kualitas Kinerja.

\section{B. IMPLIKASI}

Berdasarkan kesimpulan penelitian di atas, maka diajukan implikasi hasil penelitian ini sebagai berikut:

1. Untuk meningkatkan kualitas Pembelajaran karyawan di PT. Whitesky
Aviation diperlukan peningkatan kualitas Kompetensi.

2. Untuk meningkatkan kualitas karyawan di PT. Whitesky Aviation diperlukan peningkatan kualitas Tim Kerja.

3. Untuk meningkatkan kualitas Kinerja karyawan di PT. Whitesky Aviation diperlukan peningkatan kualitas Kompetensi.

4. Untuk meningkatkan kualitas Kinerja karyawan di PT. Whitesky Aviation diperlukan peningkatan kualitas Tim Kerja.

5. Untuk meningkatkan kualitas Kinerja karyawan di PT. Whitesky Aviation diperlukan peningkatan kualitas Pembelajaran.

\section{DAFTAR PUSTAKA}

Chambers, Essential English Dictionary, Edinburgh: Chambers Harrap Publishers Ltd., 1995.

Colquitt, Jason A., Jeffery A. LePine \& Michael J. Wesson, Organizational Behavior: Improving Performance and Commitment in the workplace, Second Edition. NY: McGraw-Hill Irwin, 2011

Dessler, Gary, Human Resource Management, Eleventh Edition. New Jersey: Pearson Prentice Hall, 2008

Ivancevich, John M., Robert Konopaske \& Michael T. Matteson, Organizational Behavior and Management, Eighth Edition. New York: McGraw-Hill Education, 2008 
Kreitner, Robert \& Angelo Kinicki, Organizational Behavior, Eighth Edition. New York: Mc Graw-Hill/Irwin International, 2008

Luthans, Fred, Organizational Behavior, Twelfth Edition, New York: McGrawHill International Edition, 2011.

Mathis, Robert L. \& John H. Jackson, Human Resource Management: Manajemen Sumber Daya Manusia, Edisi Sepuluh. Jakarta: Penerbit Salemba Empat, 2006.

Mondy, R. Wayne, Human Resource Management, Tenth Edition, NewJersey: Pearson Prentice-Hill International Edition, 2008

Newstrom,John W., Organizational Behavior , Human Behavior at Work, Thirteenth Edition,New York: McGraw-Hill International, 2011

Noe, Raymond A. et.al., Human Resource Management: Gaining a competitive advantage, $6^{\text {th }}$ Edition, NY: McGrawHill International Edition, 2008

Robbins, Stephen P. \& Timothy A. Judge. Organizational Behavior, 13th Edition. NewJersey: Pearson Prentice Hall, 2009

Robbins, Stephen P. \& Mary Coulter, Manajemen, Jilid 1, Edisi Kesepuluh, Jakarta : Penerbit Erlangga, 2014.

Wibowo, Prof., Dr., SE, M.Phil., Manajemen Kinerja. Edisi Kedua. Jakarta: Rajawali Pers, 2012 